удк: $327.5: 355.43$

Юрій Васильович Пунда (доктор військових наук, с.н.с.)

Іван Павлович Козинець (кандидт історичних наук, с.н.с.)

Володимир Степанович Клименко (кандидат політичних наук, доцент)

Національний університет оборони Украӥни імені Івана Черняховського, Київ, Украӥна

\title{
МЕТОДОЛОГІЧНІ ПІДХОДИ ДО ВИЗНАЧЕННЯ РІВНЯ КОНФЛІКТНОСТІ МІЖДЕРЖАВНИХ ВІДНОСИН
}

У иирокому спектрі проблем забезпечення начіональної безпеки важлива роль відводиться воєнній сфері. Оиінюючи реалії сьогодення, не слід нехтувати поняттям “воєнна небезпека”, яка розглядається як потенційна можливість будь-якої держави (групи держав) щзодо застосування військової сили для вирішення міждержавних протиріч.

Незважаючи на задеклароване в стратегічних документах більшості держав та міжнародних міжурядових організацій прагнення до вирішення протиріч мирним шляхом, прогнозування результатів

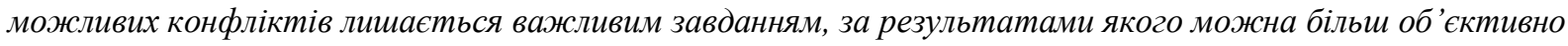
приймати воєнно-політичні рішення.

В даній статті автори поставили перед собою завдання запропонувати варіант методичного підходу до визначення рівня конфліктності міждержавних відносин, який доцільно впровадити в процес підготовки фахівців державного військового управління. Шляхом поєднання різних методик передбачається визначити ймовірний осередок можливого конфлікту та спрогнозувати його можливі результати. Авторами запропоновано ряд власних наукових та методичних доробок, щзо визначає перспективи подальших розвідок у даному напрямку досліджень, моніторингу та прогнозування рівня воєнної небезпеки з боку країн-сусідів.

Ключові слова: міждержавні відносини, воєнно-політична обстановка, воєнний конфлікт, національна безпека, національні інтереси, територіальна иүілісність, суверенітет.

\section{Вступ}

Розвиток безпекового середовища породив нові виклики та загрози національній безпеці України, які пов'язані із веденням Росією “гібридної війни” проти неї. Усе це вимагає пошуку нових дієвих засобів стримування агресора, активних кроків, в тому числі і у зовнішньополітичній сфері.

Постановка проблеми. Сьогодні досить часто виникають політичні, економічні, територіальні, етнічні та інші протиріччя у міждержавних відносинах. Особливо небезпечною $є$ тенденція відновлення “законсервованих" протиріч між державами, що мають історичне підгрунтя та виникли внаслідок розпаду соціалістичного табору. Після виходу із зони впливу колишнього “центру сили", разом із реальною незалежністю нові держави отримали і проблеми міждержавних відносин, які раніше жорстко контролювались ззовні. Не стала винятком і Україна.

Поряд 3 цим, реформування сектору безпеки i оборони України, реалізація зовнішньополітичного курсу держави, прийняття нової Стратегії національної безпеки, яка визначає загрози національній безпеці, найбільш актуальною з яких є агресивні дії Росії, вимагають постійної уваги до оцінки воєнно-політичної обстановки, прогнозування результатів можливих конфліктів, так як саме на їх підставі уточнюється зміст зовнішньополітичної діяльності держави та напрями будівництва і підготовки Збройних Сил.

Аналіз наукових досліджень і публікацій, у яких розглядається дана проблематика, показує, що іiі дослідження охоплює тривалий історичний період, хоча обгрунтовані наукові результати опубліковані відносно недавно та базуються на дослідженні періоду новітньої історії. За висновком дослідників, досягнення людства привели до того, що за характером війни “...XX ст. більше відрізняється від XIX ст., ніж XIX ст. від II ст. Сьогодні наше завдання полягає не стільки в тому, щоб вирахувати можливість виникнення війни у визначений час в певній державі чи війни між двома певними державами, стільки в тому, щоб створити умови для попередження війни чи виробити процедури, які будуть сприяти її подавленню у зародку.” [1].

Проблеми природи соціально-політичного конфлікту вивчалися Т.Мальтусом, К.Клаузевіцом, дослідниками більш пізнього періоду Р.Квінсі, вченими "мічиганської групи" 50-60-х p.p. XX ст. (К.Боулдингом, А.Рапопортом, Р.Енджелом та ін.)., М. Лундом, досліджувались у працях вітчизняних вчених М.Капітоненка, В.Косевцова, О.Маначинського, Г.Перепелиці, В.Телелима, М.Цюрупи та інших. 
Враховуючи наукові здобутки зарубіжних i вітчизняних дослідників, у даній статті автори ставлять за мету дослідити чинники і фактори, які впливають на валідність запропонованих методик оцінки конфліктності двосторонніх міждержавних відносин та на підставі їх аналізу визначити доцільність впровадження даного методологічного підходу в практичну діяльність, в першу чергу військових керівників.

\section{Виклад основного матеріалу дослідження}

Серед комплексу заходів, що здійснюються в процесі прийняття управлінських рішень у сфері національної безпеки, надзвичайно важливе місце займає прогнозування можливості вирішення міждержавних територіальних, економічних, етнічних, релігійних та інших суперечок шляхом застосування військової сили (воєнного конфлікту) будь-якою державою чи групою держав. Це вимагає комплексної оцінки великої кількості різнорідних чинників, що можуть призвести до виникнення воєнного конфлікту. Разом з тим, діяльність та структура системи забезпечення національної безпеки розподілена за сферами, що в певній мірі виправдано для раціонального розподілу повноважень між іiі структурними елементами [2]. Проте такий підхід має і недоліки, зокрема складність налагодження ефективної горизонтальної взаємодії між окремими елементами в процесі розробки та прийняття важливих рішень, що виходить за межі однієї сфери.

Тому в процесі підготовки та прийняття важливих рішень у сфері національної та воєнної безпеки, вибору найкращого варіанта із запропонованих, об'єктивно необхідна методика, що дозволить оперативно, із залученням доступних вихідних даних і обмеженої кількості експертів, з високою ймовірністю оцінити рівень напруженості двосторонніх відносин між Україною та іншими державами, прогнозувати наслідки прийняття варіантів воєнно-політичного рішення для вибору найменш конфліктогенного.

У сьогоднішній практиці прийняття воєннополітичних рішень використовуються методики, які дозволяють визначити рівень національної, воєнної, безпеки, небезпек та загроз. Вони застосовуються для оцінки існуючого стану i потребують великих часових витрат, залучення значної кількості компетентних експертів [3]. Для оперативного розрахунку наслідків прийняття воєнно-політичних рішень у сфері оборони необхідна нескладна, але досить точна методика прогнозування результатів можливого воєнного конфлікту. Очевидно, що така методика має базуватись на основі всебічного аналізу імовірних суб'єктів воєнного конфлікту, на кшталт PESTаналізу - маркетингового інструменту, призначеного для виявлення політичних, економічних, соціальних і технологічних аспектів зовнішнього середовища, які впливають на бізнес.
Такий підхід у поєднанні зі SWOT-аналізом (сильні та слабкі сторони, можливості і загрози), MOST-аналізом (місія, мета, стратегії, тактика) або SCRS-аналізом (стратегія, поточний стан, вимоги, рішення) успішно використовується також i в оборонному та стратегічному плануванні.

В навчальних цілях авторами пропонується поєднання різних методик для визначення, поперше, рівня напруженості воєнно-політичної обстановки навколо України i, по-друге, оцінки результатів можливого конфлікту 3 визначеною стороною.

Під оцінкою воєнно-політичної обстановки (ВПО) розуміється результат кількісно-якісного аналізу сукупності факторів, які характеризують стан відносин між державами (коаліціями держав), їхні воєнно-економічні потенціали, розстановку, співвідношення та взаємодію на даний момент часу військових, політичних та інших сил, а також визначають ступінь напруженості відносин між державами (коаліціями держав) та рівень небезпеки виникнення воєнних конфліктів (війни) (Військовий стандарт 01.101.004 - 2015 (02) (Воєнна розвідка. Розвідувально-інформаційна діяльність. Терміни та визначення.) [4, C.4]

ВПО оцінюється в інтересах безпеки держави та здійснюється постійно, незалежно від воєнного чи мирного часу, напруженої чи спокійної обстановки довкола України. На основі результатів оцінки ВПО уточнюється зміст зовнішньополітичної діяльності держави та напрями будівництва і підготовки Збройних Сил України. Висновки з оцінки ВПО є вихідними даними для подальшої оцінки воєнно-стратегічної обстановки.

Головна мета оцінки ВПО навколо України в мирний час полягає у виявленні ступеня ㄲï напруженості, своєчасному визначенні джерел воєнної небезпеки, наявності воєнної загрози Україні, а також загроз в інших сферах та забезпеченні розробки ефективних заходів з їхньої нейтралізації для запобігання можливим конфліктам, у першу чергу збройним.

Оцінювання ВПО пропонується провести методом експертних оцінок [5]. Вихідними даними для оцінювання ВПО є інформаційні документи (розвідувальна інформація, аналітичні огляди, інформаційні бюлетені, інформаційні та інформаційно-аналітичні довідки а також довідники по країнах світу), які надаються органами воєнної розвідки, а також результати обробки інформації з відкритих джерел.

Ступінь напруженості воєнно-політичних відносин між Україною та оцінюваною країною визначається за показниками, наведеними у відповідних методиках [4, С.36-37]. У даному випадку, як приклад, пропонується наступна шкала показників (анкета, на яку дають відповіді експерти), наведена у таблиці 1.

Оцінювання проводиться за шкалою від 0 до 1, де 0 - мінімальний рівень (напруженості), 1 максимальний рівень (напруженості) як можлива 
потенційна чи реальна загроза. Підсумкові показники для спрощення розрахунків пропонується обраховувати як середне арифметичне.

За результатами оцінки воєнно-політичної обстановки визначається:

загальний стан ВПО між Україною та оцінюваною країною за ступенем напруженості;

причини, що призвели до нинішнього стану ВПО (у разі його погіршення);

ймовірна мета виявлених намірів та дій окремої країни стосовно України, рівень їх агресивності;

тенденції розвитку ВПО між Україною та окремою країною, чинники, якими вони зумовлені.

Ступені напруженості ВПО між Україною та окремою країною (коаліцією держав) пропонується визначати за методикою оцінки ВПО [4, С.37-39], застосовуючи відповідні індекси напруженості:
0 - 0,2 - спокійна;
0,3 - 0,4 - загострена;
0,5 - 0,7 - кризова;
0,8 - 0,9 - конфліктна;
$1-$ ВПО стану війни.

Таблиця 1

Оцінювання рівня напруженості двосторонніх відносин між Україною та сусідніми державами

\begin{tabular}{|c|c|c|c|c|}
\hline $\begin{array}{l}\text { № } \\
\text { 3/II }\end{array}$ & Показники & 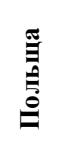 & $\theta$ & 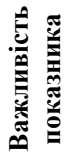 \\
\hline 1. & $\begin{array}{l}\text { Наявність територіальних претензій до } \\
\text { України }\end{array}$ & 0,4 & 0,8 & 0,6 \\
\hline 2. & $\begin{array}{l}\text { Ступінь підтримки сепаратистських сил в } \\
\text { Україні }\end{array}$ & 0,2 & 1 & 0,6 \\
\hline 3. & $\begin{array}{l}\text { Відносини з Україною у економічній, } \\
\text { фінансовій, торговій сферах }\end{array}$ & 0,2 & 0,8 & 0,5 \\
\hline 4. & Прагнення до домінування в регіоні & 0,6 & 0,9 & 0,75 \\
\hline 5. & $\begin{array}{l}\text { Співвідношення воєнних потенціалів як } \\
\text { потенційна загроза }\end{array}$ & 0,1 & 0,9 & 0,5 \\
\hline 6. & $\begin{array}{l}\text { Ступінь соціально-політичної } \\
\text { нестабільності у сусідніх країнах }\end{array}$ & 0,2 & 0,6 & 0,4 \\
\hline 7. & $\begin{array}{l}\text { Рівень впливу закордонних релігійних } \\
\text { центрів на конфесії в Україні }\end{array}$ & 0,3 & 0,9 & 0,6 \\
\hline 8. & $\begin{array}{l}\text { Заяви й акції, які дискредитують } \\
\text { внутрішню і зовнішню політику України }\end{array}$ & 0,4 & 0,8 & 0,6 \\
\hline 9. & $\begin{array}{l}\text { Наявність значних військових формувань } \\
\text { поблизу кордонів України }\end{array}$ & 0,2 & 0,9 & 0,55 \\
\hline 10 & $\begin{array}{l}\text { Спроби втручання у внутрішні справи } \\
\text { України }\end{array}$ & 0,2 & 0,9 & 0,55 \\
\hline \multicolumn{2}{|c|}{ Рівень напруженості } & $\mathbf{0 , 2 8}$ & $\mathbf{0 , 8 5}$ & \\
\hline
\end{tabular}

Застосування даної методики, дає можливість отримати вихідні дані для наступного етапу дослідження. Після визначення ймовірного осередку конфлікту необхідно спрогнозувати його можливі результати. В цьому аспекті достатньо ефективною виявилася методика прогнозування результатів можливого міжнародного конфлікту по К. Райту [6]. Він запропонував обирати в якості вихідних даних: рівень важливості національних інтересів, які відстоюються в конфлікті; бойові можливості угруповань військ, що безпосередньо беруть участь у збройному протистоянні; вартість ресурсного забезпечення конфлікту; вплив світової спільноти на учасників конфлікту; воєнноекономічні потенціали сторін, включаючи можливості союзників; рівень можливих втрат у ході воєнних дій.

Методику оцінки результатів можливого міжнародного конфлікту (Dx) між сторонами X та $\mathrm{Y}$ у визначений момент оцінки (dt) по Квінсі Райту [6] можна подати у вигляді:

$$
\begin{aligned}
& \mathrm{D}_{\mathrm{x}} / \mathrm{d}_{\mathrm{t}}=\left(\mathrm{N}_{\mathrm{x}}+\mathrm{F}_{\mathrm{x}}\right)-\left(\mathrm{C}_{\mathrm{x}}+\mathrm{W}_{\mathrm{x}}\right)+\left(\mathrm{P}_{\mathrm{x}}-\mathrm{P}_{\mathrm{y}}\right)-\left(\mathrm{V}_{\mathrm{x}}-\mathrm{V}_{\mathrm{y}}\right), \\
& \mathrm{D}_{\mathrm{y}} / \mathrm{d}_{\mathrm{t}}=\left(\mathrm{N}_{\mathrm{y}}+\mathrm{F}_{\mathrm{y}}\right)-\left(\mathrm{C}_{\mathrm{y}}+\mathrm{W}_{\mathrm{y}}\right)+\left(\mathrm{P}_{\mathrm{y}}-\mathrm{P}_{\mathrm{x}}\right)-\left(\mathrm{V}_{\mathrm{y}}-\mathrm{V}_{\mathrm{x}}\right)
\end{aligned}
$$

де: $\mathrm{Nx}$ i $\mathrm{Ny} \mathrm{-} \mathrm{рівень} \mathrm{важливості} \mathrm{національних}$ інтересів відповідно для суб'єктів X i Y, які відстоюються у конфлікті;

Fx i Fy - бойові потенціали угруповань військ сторін X і Y, що безпосередньо беруть участь у збройному протистоянні;

Сх і Су - «вартість» конфлікту для сторін X і Y ( витрати на озброєння, матеріальні i людські втрати);

Wx i Wy - тиск на сторони X і Y світової громадської думки на користь мирного вирішення конфлікту;

Pх і Ру - воєнно-економічні потенціали сторін $\mathrm{X}$ i Y (включаючи союзників);

Vx i Vy - рівень можливих втрат сторін X i Y у ході воєнних дій.

Розраховане чисельне значення вказує ступінь готовності до нарощування або згортання конфлікту. За матеріалами іноземних видань зазначена методика була апробована на даних 45 конфліктів [8], що відбулися в світі після Другої світової війни та довела свою високу ефективність. Разом 3 тим, детальних відомостей про порядок отримання вихідних даних та прикладів використання методики, в силу специфіки області застосування, у відкритих джерелах немає.

Запропоновані К. Райтом підходи можна охарактеризувати таким чином:

методика відображає домінуючий на заході прагматичний підхід до прийняття рішень у галузі воєнної безпеки в цілому, і стосовно участі в воєнному конфлікті зокрема. Сутність такого підходу полягає в тому, що рішення про підготовку або початок воєнного конфлікту приймається на основі ретельного аналізу співвідношення можливих втрат та виграшів як у результаті розгортання воєнного конфлікту, так і у випадку пасивної реакції;

в основу розрахунків покладено, так би мовити, „математизацію” основних законів війни;

- в методиці пропонується вважати рівними вагові коефіцієнти всіх чинників;

в методиці занадто опосередковане врахування, що зведене до врахування суспільної думки;

не враховуються непередбачувані обставини, що завжди істотно впливають на результат воєнного конфлікту.

Тому напрямами формування придатної для оперативних розрахунків методики прогнозування результатів можливого воєнного конфлікту можна вважати введення вагових коефіцієнтів для Modern Information Technologies in the Sphere of Security and Defence $\mathcal{N} N$ o 3(36)/2019 $\quad$ ISSN2311-7249(Print)/ISSN2410-7336(Onfine) $\quad 153$ 
кожного компоненту, додаткове врахування морального та інтелектуального чинників та врахування невизначеності.

Залишаючи в основі розрахунків прагматичний підхід, необхідно детальніше зупинитись на закономірностях, що встановлюють залежність ходу i результатів конфліктів від різнорідних чинників, які i будуть покладатись в основу розрахунків.

Питання ведення війни i вибору найкращої стратегії для перемоги розглядалось філософами 3 античних часів на протязі всієї історії людства. Довели свою життєздатність погляди Сун-цзи, який вважав, що перемога залежить від „Дао, Неба, Землі, Полководця і Закону”. Надалі закони та закономірності війни були узагальнені, проте можливість використання їх для математичних розрахунків та розробки рекомендацій для воєннополітичного керівництва не розглядалась.

Слід також зазначити, що в теоретичних доробках вітчизняних вчених існує низка фундаментальних положень, які дозволяють прогнозувати результати можливого міжнародного воєнного конфлікту 3 високим ступенем імовірності та пропонується низка закономірностей збройної боротьби [7].

Можливість об’єднання закономірностей у групи та врахування підходів, запропонованих К.Райтом, дозволяють по-новому підійти до прогнозування результатів можливого міждержавного воєнного конфлікту. Зокрема, додатково врахувати рівень розвитку воєнного мистецтва сторін учасниць конфлікту, готовність населення i особового складу збройних сил до ведення конфлікту, та врахувати непередбачувані обставини, які майже завжди виникають у ході ведення конфлікту.

Придатну для використання в практиці функціонування воєнної сфери держави методику оперативного прогнозування результатів можливого воєнного конфлікту у визначений період часу в загальному вигляді можна запропонувати в такому вигляді:

$\mathrm{D}_{\mathrm{x}} / \mathrm{d}_{\mathrm{t}}=\mathrm{k}_{\mathrm{N}} \mathrm{N}_{\mathrm{x}}+\mathrm{k}_{\mathrm{F}} \mathrm{F}_{\mathrm{x}}-\mathrm{k}_{\mathrm{C}} \mathrm{C}_{\mathrm{x}}-\mathrm{k}_{\mathrm{W}} \mathrm{W}_{\mathrm{x}}+\mathrm{k}_{\mathrm{P}}\left(\mathrm{P}_{\mathrm{x}}-\right.$

$\left.\mathrm{P}_{\mathrm{e}}\right)-\mathrm{k}_{\mathrm{V}}\left(\mathrm{V}_{\mathrm{x}}-\mathrm{V}_{\mathrm{y}}\right)+\mathrm{k}_{\mathrm{M}}\left(\mathrm{M}_{\mathrm{x}}-\mathrm{M}_{\mathrm{y}}\right)+\mathrm{k}_{\mathrm{S}} \mathrm{S}_{\mathrm{x}}+\delta$;

$\mathrm{D}_{\mathrm{y}} / \mathrm{d}_{\mathrm{t}}=\mathrm{k}_{\mathrm{N}} \mathrm{N}_{\mathrm{y}}+\mathrm{k}_{\mathrm{F}} \mathrm{F}_{\mathrm{y}}-\mathrm{k}_{\mathrm{C}} \mathrm{C}_{\mathrm{y}}-\mathrm{k}_{\mathrm{W}} \mathrm{W}_{\mathrm{y}}+\mathrm{k}_{\mathrm{P}}\left(\mathrm{P}_{\mathrm{y}}-\right.$

$\left.\mathrm{P}_{\mathrm{x}}\right)-\mathrm{k}_{\mathrm{y}}\left(\mathrm{V}_{\mathrm{y}}-\mathrm{V}_{\mathrm{x}}\right)+\mathrm{k}_{\mathrm{M}}\left(\mathrm{M}_{\mathrm{y}}-\mathrm{M}_{\mathrm{x}}\right)+\mathrm{k}_{\mathrm{S}} \mathrm{S}_{\mathrm{y}}+\delta$

де: $\mathrm{kN}, \mathrm{kF}, \mathrm{kC}, \mathrm{kW}, \mathrm{kP}, \mathrm{kV}, \mathrm{kM}, \mathrm{kS}$ - коефіцієнти відносної важливості;

$\mathrm{Nx}$ i Ny - рівень важливості національних інтересів для суб'єктів X і Y, які відстоюються в конфлікті;

Fx i Fy - бойові потенціали угруповань військ сторін X і Y, що безпосередньо беруть участь у збройному протистоянні;

Cx i Су - відносна вартість конфлікту для сторін X і Y ( витрати на озброєння, матеріальні і людські втрати);

Wx i Wy - тиск на сторони X i Y світової громадської думки на користь мирного вирішення конфлікту;

Px і Ру - воєнно-економічні потенціали сторін $\mathrm{X}$ i Y (включаючи союзників);

Vx i Vy - рівень можливих втрат сторін X і Y в ході воєнних дій;

Мх і Му - рівень розвитку воєнного мистецтва сторін X і Y;

$\mathrm{Sx}$ i Sy - готовність населення i особового складу збройних сил сторін X i Y до ведення конфлікту;

$\delta$ - коефіцієнт невизначеності.

Значення всіх складових формули доцільно стандартизовувати та розглядати в межах від 0 до 1.

Зокрема:

коефіцієнти важливості (k) доцільно обчислювати методами експертних оцінок та аналізу ієрархій;

рівень важливості національних інтересів (Nx i Ny) оцінювати методом експертних оцінок у межах від 0 до 1, де 0 - другорядний інтерес, 1 життєво важливий інтерес;

бойові можливості угруповань військ, що безпосередньо беруть участь у збройному протистоянні (Fx i Fy) оцінювати за формулами $F_{x}=\frac{B_{x}}{B_{x}+B_{y}}, F_{y}=\frac{B_{y}}{B_{x}+B_{y}}$, де Вх, Ву - бойові потенціали збройних сил сторін після приведення його до вигляду Вх:Ву.

відносну вартість конфлікту для сторін X і Y оцінювати в співвідношенні витрат на ведення конфлікту та внутрішнього валового продукту за формулою $C_{x}=\frac{K_{x}}{E_{x}}, \quad C_{y}=\frac{K_{y}}{E_{y}}$, де $\mathrm{Kx}, \mathrm{Ky}-$ вартість матеріальних витрат і втрат для сторін; Ех, Еу - золотовалютний резерв сторін X і Y;

тиск світової громадської думки на користь мирного вирішення конфлікту оцінювати методом експертних оцінок у межах від 0 до 1 , де 0 - не сприйняття світової думки воєнно-політичним керівництвом сторони, 1 - повне підпорядкування вимогам світової спільноти;

воєнно-економічні потенціали сторін визначати через співвідношення золотовалютних сторін конфлікту $P_{x}=\frac{E_{x}}{E_{x}+E_{y}}, P_{y}=\frac{E_{y}}{E_{x}+E_{y}}$, де $\mathrm{Ex}$, Еу - золотовалютний резерв сторін $\mathrm{X}$ i Y.

рівень можливих втрат сторін оцінювати методом експертних оцінок у межах від 0 до 1, де 0 - невідчутні втрати, 1- неприпустимі втрати;

рівень розвитку воєнного мистецтва сторін $\mathrm{X}$ i Y оцінювати методом експертних оцінок у межах від 0 до 1;

готовність населення i особового складу збройних сил сторін X і Y до ведення конфлікту оцінювати методом експертних оцінок у межах від 0 до 1 ;

$\delta$ - коефіцієнт невизначеності враховує непередбачувані чинники, які можуть виникнути в 
ході ведення конфлікту і дозволяє відображати результати розрахунків у визначеному інтервалі. Коефіцієнт невизначеності пропонується визначати в інтервалі (-0,5:0,5).

За такого варіанта отримання вихідних даних значення Dx/dt та Dy/dt може коливатись у межах від $-5,5$ до $+5,5$.

Якщо результат розрахунку має від'ємне значення, це свідчить про несприятливий прогноз результату конфлікту і вимагатиме термінового управляючого впливу.

Для аналізу розрахунків доцільно використовувати шкалу оцінки результатів можливого конфлікту (рис.1).

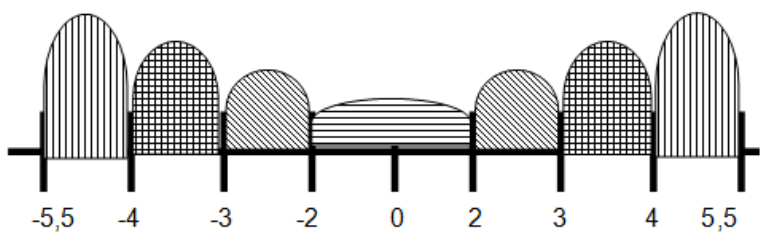

Рис.1. Шкала оцінки результатів можливого конфлікту

Результати оцінки в межах від -2 до 2 вказують, що конфлікт $\epsilon$ малоймовірним через незначні шанси досягнення мети будь-якою з сторін.

Результати оцінки в межах від 2 до 3 в залежності від знаку результату розрахунків вказують на зростання імовірності розв'язання конфлікту.

Результат оцінки в межах від 3 до 4 свідчать про готовність однієї зі сторін до розгортання

\section{Лimepamypa}

1. Wright Q. Problems of Stability and Progress of International Relations. Politics and International Stability. Berkeley and Los Angeles: University of California Press, 1954. Р. III. Ch. 8. Р. 129. 2. Закон України "Про національну безпеку України" від 21.06.2018 р. № 2469VIII. 3. Косевцов В. О., Телелим В. М., Шевченко В. I. Оцінка стану воєнної безпеки України // Наука i оборона. - 1998. №2 - С. 3-6. 4. Методика оцінки воєнно-політичної обстановки. - К.: НДІ ГУР МОУ, 2016. - 82 с. дск, інв. НУОУ № 16613. 5. Грабовецький Б. С. Методи експертних оцінок: теорія, методологія, напрямки використання: воєнного конфлікту.

Оцінки в межах від 4 до 5,5 свідчать про фактичну невідворотність конфлікту 3 прогнозованим результатом [8].

\section{Висновки і перспективи подальших}

\section{досліджень}

Запропонований варіант поєднання методик визначення рівня конфліктогенності у міждержавних відносинах та прогнозування результатів можливого воєнного конфлікту дозволяє оперативно, із залученням доступних вихідних даних і обмеженої кількості експертів, 3 високою ефективністю прогнозувати наслідки прийняття воєнно-політичного рішення 3 більш повним врахуванням чинників, що впливають на хід і результат конфлікту.

Таким чином, використання результатів проведеного дослідження дозволяе прогнозувати результати можливого воєнного конфлікту та обгрунтовувати шляхи зниження рівня напруженості у взаємовідносинах між країнами регіону. Перспективами подальших розвідок у даному напрямку досліджень $\epsilon$ моніторинг та прогнозування рівня воєнної небезпеки для України з боку країн-сусідів.

Надалі методика прогнозування результатів можливого воєнного конфлікту може бути доведена до програмного продукту і забезпечити автоматизацію процесу визначення вихідних даних і отримання результатів розрахунків.

монографія / - Вінниця: ВНТУ, 2010. - 171 с. 6. Wright $\mathbf{Q}$. The escalation of International Conflict/ - The Journal of Conflict Resolution. 1965. Vol. IX. №4. p.435. 7. Щипанський П.В., Крикун П.М., Устименко О.В. Нове безпекове середовище - прогнозовані виклики та загрози національній безпеці України // Збірник наукових праць Центру воєнно-стратегічних досліджень Національного університету оборони України імені Івана Черняховського. - №1(53), 2015. - С.107-112. 8. Пунда Ю.В. Методика прогнозування результатів можливого воєнного конфлікту. Труди академії, - № $1(88),-2009,-$ c. $40-46$.

\title{
МЕТОДОЛОГИЧЕСКИЕ ПОДХОДЫ К ОПРЕДЕЛЕНИЮ УРОВНЯ КОНФЛИКТНОСТИ МЕЖГОСУДАРСТВЕННЫХ ОТНОШЕНИЙ
}

\author{
Юрий Васильевич Пунда (доктор военных наук, с.н.с.) \\ Иван Павлович Козинец (кандидат исторических наук, с.н.с.) \\ Владимир Степанович Клименко (кандидат политических наук, доцент)
}

\section{Национальный университет обороны Украины имени Ивана Черняховского, Киев, Украина}

В широком спектре проблем обеспечения национальной безопасности важная роль определена военной сфере. Оиенивая реальности сегодняшнего дня, не следует пренебрегать понятием "военная опасность”, которая рассматривается как потенциальная возможность любого государства (группь государств) относительно применения военной силь для решения межгосударственньх противоречий.

Несмотря на задекларированное в стратегических документах большинства государств $u$ международных межправительственных организаций стремление к ремению противоречий мирным 
путем, прогнозирование результатов возможных конфликтов остается важной задачей, за результатами которой можно более объективно принимать военно-политические решения.

В данной статье авторы поставили перед собой задачу предложить вариант методического подхода $к$ определению уровня конфликтности межгосударственных отношений, который целесообразно внедрить в процесс подготовки специалистов государственного военного управления. Путем последовательного применения различных методик предполагается определить возможный очаг конфликта и спрогнозировать его возможные результаты. Авторами предложено ряд собственных научных и методических доработок, что определяет перспективы дальнейших поисков в данном направлении исследований, мониторинге и прогнозировании уровня военной опасности со стороньл соседних государств.

Ключевые слова: межгосударственные отношения, военно-политическая обстановка, военный конфликт, национальная безопасность, национальные интересы, территориальная целостность, суверенитет.

\title{
METHODOLOGICAL APPROACHES TO DETERMINING THE CONFLICT LEVEL OF INTER- STATE RELATIONS
}

\author{
Yuri Punda (Doctor of Military Sciences, PhD) \\ Ivan Kozynets (Candidate of Historical Sciences, PhD) \\ Volodymyr Klimenko (Candidate of Political Science, Associate Professor)
}

\author{
National Defence University of Ukraine named after Ivan Cherniakhovsky, Kyiv, Ukraine
}

Military field plays an important role among a wide range of national security issues,. In assessing the realities of today, we should not neglect the concept of "military danger", which is seen as a potential opportunity of any state (group of states) to use military force to resolve interstate contradictions.

Despite the stated in the strategic documents of the majority of states and international intergovernmental organizations the desire to resolve conflicts peacefully, the results prediction of possible conflicts remains an important task and can help to make military and political decisions more objectively.

In this article, the authors have set the task of proposing a methodological approach to determining the level of conflict of interstate relations, which should be implemented in the process of stafe military management training. By combining different techniques, it is intended to determine the likely focus of a possible conflict and predict its possible outcomes. The authors propose a number of their own scientific and methodological achievements, which determines the prospects for further research, monitoring and forecasting of the level of military danger by neighboring countries.

Key words: interstate relations, military-political situation, military conflict, national security, national interests, territorial integrity, sovereignty.

\section{References}

1. Wright Q. Problems of Stability and Progress of International Relations. Politics and International Stability. Berkeley and Los Angeles: University of California Press, 1954. P. III. Ch. 8. P. 129. 2. Law of Ukraine "On National Security of Ukraine" dated 21.06.2018 № 2469-VIII. 3. Kosevtsov V.A., Telelim V.M., Shevchenko V.I. Evaluation of the state of military security of Ukraine // Science and Defense. - 1998. №2 - P. 3-6. 4. Methods of evaluation of the military-political situation. - K .: MOU GUR Research Institute, 2016. - 82 p. board, inv. 5. Grabovetskyy B. E. Expert Assessment Methods: Theory, Methodology, Directions of Use: Monograph / -
Vinnytsia: VNTU, 2010. - 171 p. 6. Wright Q. The escalation of International Conflict/ - The Journal of Conflict Resolution. - 1965. - Vol. IX. - №4- p.435. 7. Shchipanskiy P.V., Krykun P.M., Ustymenko O.V. New Security Environment - Predictable Challenges and Threats to National Security of Ukraine // Collection of scientific papers of the Center for Military-Strategic Studies of Ivan Chernyakhovsky National University of Defense of Ukraine. - №1 (53), 2015. - P.107-112. 8. Punda Y.V. Methods for predicting the outcome of a possible military conflict // Proceedings of the Academy, - № 1 (88), - 2009, p. $40-46$. 